\title{
Evaluasi Kandungan Nutrisi Pakan dan Daya Hambat Tepung Biji Asam Kandis (Gracinia cowa) sebagai Bahan Pakan Unggas
}

\author{
Febri Puska Padang ${ }^{*}$, Osfar Sjofjan², Edhy Sudjarwo ${ }^{2}$ \\ ${ }^{1}$ Mahasiswa Program Pascsarjana Fakultas Peternakan Universitas Brawijaya \\ ${ }^{2}$ Dosen Bagian Nutrisi Dan Makanan Ternak Fakultas Peternakan Universitas Brawijaya \\ Jl. Veteran, Malang 65145 \\ *Email korespondensi: febripadang2294@gmail.com
}

(Diterima: 16-8-2018; disetujui 1-9-2018)

\begin{abstract}
ABSTRAK
Asam kandis (Gracinia cowa) telah banyak digunakan untuk masakan, pengobatan, kecantikan dll, namun penggunaan biji belum maksimal sehingga terbuang sia-sia. Biji dapat dimanfaatkan sebagai sebagai fitobiotik untuk menggantikan antibiotik ataupun sebagai bahan pakan. Tujuan penelitian ini untuk mengetahui kandungan zat makanan dan daya hambat bakteri terhadap tepung biji kandis. Penelitian ini dilakukan dengan percobaan laboratorium menggunakan tepung biji kandis sebagai materi, pada uji kandungan pakan menggunakan uji proksimat, uji kandungan zat aktif menggunakan uji flavonoid kuantitaf sekunder, sedangkan uji daya hambat mengunakan metode sumuran. Hasil dari uji tersebut adalah bahan kering 89,11\%, lemak kasar 4,77, serat keras 18,57, protein kasar 0,99, tanin 0,29\%, GE $5244 \mathrm{kkal} / \mathrm{kg}$, Ca $0,72 \%$, P $0,22 \%$, flavonoid 0,44 , kerapatan $413 \mathrm{~g} / \mathrm{mL}$ sedangkan daya hambat bakteri yang terkecil dihasilkan Bakteri asam laktat lalu Salmonella dan Escherichia coli. Kandungan zat makanan ini menyatakan bahwa biji asam kandis mengandung nilai nutrisi yang dapat digunakan sebagai pakan serta terdapat nilai hambat bakteri oleh adanya aktivitas flavonoid dan tanin pada biji asam kandis. Kesimpulannya bahwa biji asam kandis berpotensi sebagai bahan pakan maupun fitobiotik.
\end{abstract}

Kata kunci: Gracinia cowa, flavonoid, uji proksimat, daya hambat

\section{ABSTRACT}

Kandis acid (Gracinia cowa) has been used for cooking, medicine, beauty, etc., but using of seeds has not been profitable so it was wasted. Seeds can be used as a fitobiotic to replace antibiotics or as feed ingredients. The purpose of this study was to determine the food ingredient and the inhibitory of bacteria on kandis seeds flour. This research was conducted by laboratory experiments using Kandis seeds flour as a material, analysis proximate used to represent the composition of feedstuft, bioactive used test flavonoid quantitaf seconder and the inhibitory test with hollow diffusion methode. The results of the test were dry matter $89.11 \%$, crude fat 4.77 , fiber 18.57 , crude protein 0.99 , tannin $0.29 \%$, GE $5244 \mathrm{kcal} / \mathrm{kg}$, Ca $0.72 \%$, P $0,22 \%$, flavonoids $0.44 \%$, density $413 \mathrm{~g} / \mathrm{mL}$. The smallest inhibitory bacteria produced by lactic acid bacteria then Salmonella and Escherichia coli. The food ingredient represented that value Kandis acid seeds flour can be used as food and there are bacterial inhibitory by the activity of flavonoids and tannins. The conclusion is the kandis acid seeds have potential as feed ingredients and phytobiotics

Keywords: gracinia cowa, flavonoid, proximate analysis, inhibition

\section{PENDAHULUAN}

Asam kandis (Garcinia cowa) merupakan tanaman dari spesias Garcinia yang spesimen mencapai 64 jenis (Garcinia sp.) Kalimantan merupakan keanekaragaman tertinggi
(25 jenis) jika dibandingkan dengan pulau-pulau lain di Indonesia (Uji, 2007). Asam kandis merupakan salah satu dari enam spesies Garcinia tersebar secara sporadis di Lembah Brahmaputra, India, ukuran daun adalah 7-11 x $4-7 \mathrm{~cm}$ dengan bentuk bulat memanjang, buahnya agak 
membulat, meruncing, dengan diameter mencapai $9 \mathrm{~cm}$, berwarna jingga pucat atau kuning pekat, buah terdiri dari kulit buah dan 4 hingga 5 biji yang masing-masing diselimuti daging buah. Tumbuh pada bulan Juni-Agustus (Baruah and Borthakur, 2012). Garcinia cowa Roxb. (Guttiferae, Cluciaceae), secara umum dikenal dengan nama manggis hutan atau kandis di daerah Sumatera Barat dan cha muang di Thailand. Bagian-bagian dari tumbuhan asam kandis telah lama digunakan dalam pengobatan tradisional, diantaranya kulit batang, getah dan akar yang biasa digunakan sebagai antipiretik (Ritthiwigrom et al., 2013). Kandungan senyawa metabolit sekunder (fitokimia) akan aman dan efektif terhadap bakteri tertentu sehingga untuk pertumbuhan dan pelinudng kesehatan. Ekstrak tumbuhan digunakan dalam pakan sebagai promotor yang memiliki potensi sebagai antibakteri sinergis atau potensiator agen antibakteri lainnya (Abreu et al., 2012).

Asam Kandis (Garcinia cowa) merupakan senyawa dengan aktivitas antimikroba yang sangat tinggi (Ardiningsih et al., 2012). Tanaman sekelas dengan Gracinia cowa telah banyak digunakan untuk penyembuhan dan memiliki kandungan antibakteri yang baik, sehingga penggunaan biji asam kandis akan menghasilkan nilai yang positif pada pakan dan ternak. Firdaus et al. (2007) menyatakan pada penelitiannya bahwa asam kandis menghasilkan nilai yang positif terhadap uji saponin, flavonoid dan tanin serta Pulagenthi et al. (2004) menyatakan penggunaan biji asam terbatas karena adanya senyawa antinutrisi yakni tanin, fenol bebas, L-Dropa, asam Phitat, penghambat protease, walaupun secara medis banyak diantara senyawa tersebut bermanfaat sebagai pengobatan. Gracinia kola yang juga tanaman sekelas dengan asam kandis ini telah dimanfaatkan sebagai pakan ternak dan memberi pengaruh terhadap gambaran hematologis dan kesehatan ayam yang memperoleh bobot badan yang tinggi dan kematian yang rendah (Adedeji et al., 2006). Pemberian tepung biji Gracinia kola $5 \mathrm{~g} / \mathrm{kg}$ dapat digunakan untuk meningkatkan bobot akhir, pertambahan bobot badan pada ayam pedaging. (Mohammed dan Malik, 2013)

Penelitian bertujuan untuk mengetahui kandungan nutrisi dan daya hambat tepung biji asam kandis terhadap pertumbuhan bakteri sebagai bahan untuk pemanfaatan pakan hasil samping pertanian yang biasanya terbuang untuk ayam pedaging.

\section{MATERI DAN METODE}

\section{Materi Penelitian}

Pengolahan biji asam kandis dengan menggunakan teknologi pengolahan pembuatan tepung. Pembuatan tepung biji asam kandis dengan penggilingan biji yang telah dikeringkan yang dilaksanakan di Laboratoruium Nutrisi dan Makanan Ternak bagian Nutrisi dan Makanan Ternak (NMT) Fakultas Peternakan Universitas Brawijaya Malang.

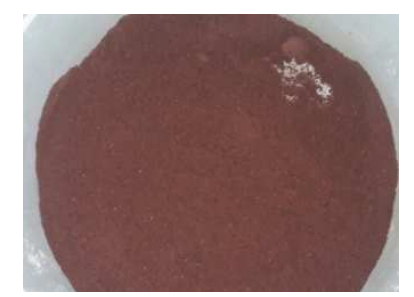

Gambar 1. Tepung biji asam kandis

\section{Metode Penelitian}

Metode penelitian yang digunakan pada penelitian tahap pertama adalah percobaan laboratorium yaitu untuk uji kandungan nutrisi tepung biji asam kandis (Garcinia cowa) menggunakan analisis proksimat, uji sifat antibakteri dengan uji daya hambat bakteri menggunakan metode sumuran $(0,50 \mathrm{~mm})$ berdasarkan metode. Uji kandungan zat aktif dengan uji flavonoid kuantitatif spektrofotometri di Laboratorium Farmasi Universitas Airlangga. Metode uji proksimat tepung biji asam kandis sesuai metode yang digunakan di Laboratorium Bagian Nutrisi dan Makanan Ternak (NMT) Fakultas Peternakan Universitas Brawijiya yaitu berdasarkan Uji proksimat Tillman (1989). Kandungan tanin diuji dengan metode analisis titrasi redoks menggunakan peraksi $\mathrm{KMnO}_{4}$ di Unit Analisis dan Pengukuran Jurusan Kimia FMIPA Universitas Brawijaya Malang. Analisa kandungan $\mathrm{Ca}$ dan $\mathrm{P}$ dilakukan dengan menggunakan spectro direct di Laboratorium Kimia Tanah Fakultas Pertanian Universitas Brawijaya. Densitas tepung biji kandis dihitung dengan cara massa $(\mathrm{g})$ dengan volume $(\mathrm{mL})$ seperti dijelaskan dalam USDA (1999).

\section{Variabel Penelitian}

Uji Proksimat menghitung kandungan nutrisi (GE, BK, PK, LK, Abu, dan SK). Uji daya hambat mikroba pada tepung biji asam kandis (Garcinia cowa) untuk menghitung terjadinya penambahan atau penurunan jumlah koloni bakteri. Uji anti nutrisi untuk melihat kandungan tanin. Uji zat aktif untuk menghitung jumlah 
flavanoid pada bahan. Uji kepadatan/densitas dilakukan untuk melihat satu unit volume yang dapat ditempati oleh massa partikel.

\section{HASIL PENELITIAN}

\section{Kandungan zat makanan}

Biji asam kandis memiliki karakteristik padat, bentuknya agak bulat dan biji dilapisi dengan kulit ari yang warna hitam dan berwarna coklat pekat dibagian dalam. Pembuatan tepung biji asam kandis melalui penggilingan biji yang telah kering menggunakan alat grinding dengan ukuran 0,6-1 $\mathrm{mm}$ di Laboratorium Nutrisi Dan Makanan Ternak Fakultas Peternakan. Hasil dari uji kandungan pakan yang telah dilakukan adalah sebagai berikut.

Tabel 1. Kandungan zat makanan pada tepung biji kandis

\begin{tabular}{ll}
\hline Zat makanan & Kandungan \\
\hline Bahan kering (\%) & 89.11 \\
Abu (\%) & 4,77 \\
Lemak kasar (\%) & 24,67 \\
Serat Kasar (\%) & 18,57 \\
Protein kasar (\%) & 0,99 \\
GE (kkal/kg) & 5244 \\
Ca \%* & 0,72 \\
P \%* & 0,22 \\
\hline
\end{tabular}

Keterangan : hasil uji proksimat di Laboratorium Nutrisi Dan Makanan Ternak Fakultas Peternakan *Laboratorium Kimia tanah Fakultas Pertanian

Hasil uji dari tepung biji asam kandis menunjukkan bahwa kandungan nutrisi yang dimiliki tidak berbeda jauh dengan kandungan nutrisi yang dimiliki oleh Gracinia kola yaitu kadar air 7,2 $\pm 0,08 \%$, protein kasar 1,86 $\pm 0,15 \%$, serat kasar $1,23 \pm 0,15 \%$, abu $0,47 \pm 0,09 \%$, lemak kasar $0,19 \pm 0,32 \%$, karbohidrat $88,30 \pm 0,08 \%$, tannin $0,342 \pm 0,00$, dan flavonoid 2,041 $\pm 0,30$ (Adesuyi et al., 2012).

Kandungan nutrisi secara proksimat menghasilkan kandungan BK sebanyak 89,11\%. Secara sederhana bahan bakan dibagi dalam dua bagian utama yaitu air dan zat kering. Zat kering mengandung energi, protein, lemak, serat mineral dan vitamin, sehingga penting untuk mengetahui kandungan bahan kering dalam bahan. Bahan kering ditentukan dengan sampel pakan di oven pada suhu $105^{\circ} \mathrm{C}$ yang akan menguapkan semua kelembaban. Fedha et al. (2010) menyatakan bahwa kelembaban pada biji akan mempengaruhi bahan kering. Semakin tinggi kelembabannya semakin rendah hasil kering sehingga informasi tersebut akan membantu penyimpanan dan pengolahan pakan, biji memiliki kandungan bahan kering yang lebih tinggi sehingga durasi penyimpanannya akan lebih lama.

Lemak kasar yang dihasilkan pada tepung biji asam kandis merupakan komponen yang tinggi mencapai $24,67 \%$. Pugalenthi, et al (2004) menyatakan bahwa kandungan asam lemak pada biji asam sangat tinggi dan kandungannya banyak yang tidak dimiliki pakan lain yakni asam lignoset (lignocenic acid) yaitu asam lemak jenuh. Menurut Ly (2017), biji asam mengandung protein asam amino dan lemak yang tergolong tinggi. Selain kandungan lemak kasar, kandungan serat kasar juga memiliki nilai yang tinggi yaitu $18,57 \%$. Kemampuan unggas dalam memanfaatkan serat kasar sangat rendah namun kandungan ini tetap diperlukan untuk keseimbangan histologi pada penceraan unggas (Incharoen, 2013).

Kandungan tepung biji asam kandis lainnya yang berpotensi adalah kandungan gross energy yaitu sebesar $5244 \mathrm{kkal} / \mathrm{kg}$. Energi berfungsi bagi aktivitas fisik, mempertahankan suhu tubuh, metabolisme, pembentukan jaringan, reproduksi dan produksi, serat kadar juga menjadi faktor dalam mencapai jumlah energi metabolisme yang akan ditentukan (McDonald et al., 1994),

\section{Kandungan Zat Aktif dan Density}

Uji densitas digunakan dalm menentukan penanganan, penyimpanan dan pengolahan. Tinggi densitas berpengaruh pada daya campur dan ketelitian penakaran, mengurangi keambaan, mengurangi tempat penyimpanan, dan mudah dalam penyajiannya. Density yang tinggi akan meningkatkan konsumsi pakan karena tidak banyak pakan yang tercecer (Krisnan, 2009).

Tabel 2. Kandungan zat aktif dan density tepung biji asam kandis

\begin{tabular}{lc}
\hline \multicolumn{1}{c}{ Zat aktif } & Kandungan \\
\hline Flavonoid (\%)* & 0,48 \\
Tanin $(\%)^{* *}$ & 0,29 \\
Density (g/L) & 583 \\
\hline
\end{tabular}

Keterangan : hasil uji laboratorium

*Laboratorium Farmasi Universitas Airlangga

** Laboratorium Hama dan Penyakit Tanaman Universitas Brawijaya

Berdasarkan uji kandungan zat aktif dari tepung biji asam kandis ditemukan bahwa tepung ini memiliki kandungan flavonoid yang dapat berfungsi sebagai antioksida. Pada penelitian yang dilakukan oleh Ouyang (2016) menyatakan bahwa flavonoid pada tumbuhan 
dapat mempengaruhi pada keefektifan dalam kenaikan harian rata-rata dan presentasi dada, kualitas daging dan meningkatkan aktivitas antioksidan. Selain itu tepung biji, asam kandis juga memiliki kandungan tanin yang dapat menurunkan performa pertumbuhan ayam apabila diberikan pada jumlah yang tinggi $(3 \%)$ tetapi dapat juga menghambat pertumbuhan bakteri patogen pada pencernaan ayam pada pemberian hingga 1\% (Hughes et al. 2005).

\section{Daya Hambat Mikroorganisme}

Tabel 3. Daya hambat mikroba tepung biji asam kandis

\begin{tabular}{|c|c|c|}
\hline Perlakuan & Test & $\begin{array}{c}\text { Daya } \\
\text { hambat } \\
(\mathrm{mm})\end{array}$ \\
\hline Kontrol & - & 0 \\
\hline $\begin{array}{l}\text { Bakteri Asam Laktat } \\
\left(2,5 \times 10^{7} \mathrm{cfu} / \mathrm{mL}\right)\end{array}$ & + & 0,233 \\
\hline $\begin{array}{l}\text { Bakteri Escherichia coli } \\
\left(4,4 \times 10^{3} \mathrm{cfu} / \mathrm{mL}\right)\end{array}$ & + & 0,67 \\
\hline $\begin{array}{l}\text { Bakteri Salmonella } s p \\
\left(3,5 \times 10^{3} \mathrm{cfu} / \mathrm{mL}\right)\end{array}$ & + & 0,543 \\
\hline
\end{tabular}

Hasil uji laboratorium pada daya hambat mikroba pada tepung biji asam kandis terdapat adanya kandungan berpotensi pada tepung biji kandis meskipun kandungan daya hambat termasuk pada daya hambat lemah. Zona hambat tertinggi adalah pada bakteri $E$. coli diikuti dengan bakteri Salmonella dan dilanjutkan dengan bakteri asam laktat sebagai bakteri yang paling rendah zona hambatnya. Uji daya hambat dilakuakn berdasarkan pendapat Holo et al. (1991), yaitu metode didusi sumuran yaitu menginjeksikan larutan biji asam kandis pada media agar yang sudah memadat. Setelah itu dilakukan inkubasi selama 24 jam untuk mengamati pertumbuhan bakteri disekeliling sumuran untuk menghitung zona hambatan. Zona hambat akan ditunjukkan dengan diameter zona bening, apabila $10-20 \mathrm{~mm}$ maka dapat disimpulkan dapat menghambat pertumbuhan bakteri dengan daya hambat kuat, sedangkan apabila 5-10 $\mathrm{mm}$ bahan tersebut mempunyai daya hambat yang sedang, dan diameter zona bening kurang dari $5 \mathrm{~mm}$ maka bahan tersebut memiliki daya hambat yang lemah (Davis and Stout, 1971).

Zona hambat yang terbentuk pada pemberian tepung biji asam kandis dipengaruhi oleh adanya kandungan tanin (Firdaus et al., 2007) dan flavonoid (Syamsudin et al., 2007) yang berfungsi sebagai antibakteri. Flavonoid dapat menghambat pertumbuhan bakteri, dengan penghambatan sintesa asam nukleat, cincin A dan B sehingga terjadi penghambatan pembentukan
DNA dan RNA sehingga terjadi kerusakan permeabilitas dinding sel bakteri, mikrosom dan lisosom. Tanin juga dapat berperan aktif dalam menghambat pertumbuhan bakteri dengan menonaktifkan adhesin sel mikroba juga menonaktifkan enzim dan merusak penceranaan protein pada lapisan dalam sel (Cowan, 1994). Namun dengan pemberian tanin sebanyak 0,33\% pada ayam maka akan menyebabkan pakan menjadi sulit dicerna oleh enzim-enzim pencernaan sehingga penghilangan tanin dapat dilakukan dengan dengan perendaman dalam air, perendaman dalam larutan alkali, cara mekanis, dan suplementasi donor methil (Widodo, 2014).

\section{KESIMPULAN}

Biji asam kandis memiliki kandungan nutrisi yang dapat dimanfaatkan pada ternak selain itu kandungan flavonoid pada biji asam kandis juga akan berfungsi sebagai zat antibakteri.

\section{DAFTAR PUSTAKA}

Abreu A.C., A.J. McBain, \& M. Simoes. 2012. Plants as sources of new antimicrobials and resistance-modifying agents. Nat. Prod. Rep. 29 1007-1021

Adedeji, O.S., G.O. Farinu, S.A. Ameen, \& T.B. Olayeni. 2006. The effects of dietary bitter kola (Garcinia kola) inclusion on body weight, haematology and survival rate of pullets chicks. J.Anim.Vet. Adv. 5(3):184-187. http://medwelljournals.com/ abstract/?doi=javaa.2006.184.187.

Adesuyi, A.O., I.K. Elumm, F.B. Adaramola, \& A.G.M. Nwokocha. 2012. Nutritional and phytochemical screening of Garcinia kola. Advance journal of food science and technology 4(1):9-14

Ardiningsih, P., Sumarni, Nofiani, \& A. Jayuska. 2012. Phythochemical screening and antimicrobial activity of sub fractions asam kandis (Garcinia diocia Blume) . Journal of Applied Pharmaceutical Science 2(12):172-174.

Baruah \& Borthakur. 2012. Studies on morphology and ethnobotany of six species of Garcinial. (Clusiaceae) found in the Brahmaputra valley, Assam, India. J. Nat. Prod. Plant Resour. 2(3):389-396.

Cowan, M.M. 1999. Plant Products As Antimicrobial Agents. Clinical Microbiology Reviews. Vol 12:564-582. 
Davis W.W. \& T.R. Stout. 1971. Disc Plate Method Of Microbiological Antibiotic Assay. Journal of Microbiology 22 (4):659-665.

Fedha, M.S., M.A. Mwasaru, C.K. Njoroge, N.O. Ojijo, \& G.O. Ouma, 2010. Effect of drying on selected proximate composition of fresh and processed fruits and seeds of two pumpkin species. Agriculture and Biology Journal of North America 1(6):1299-1302. https://doi.org/10.5251/ Abjna.2010.1.6.1299.1302

Firdaus, A., Rahminiwati, \& Wiendarlina. 2007. Efektivitas antihiperglikemik ekstrak etil asetat buah asam kandis (Garcinia Parvifolia (Miq.) terhadap tikus putih sprague-dawley jantan secara in vivo. Universitas Pakuan. Bogor.

Holo, H., Nilssen, \& I.F. Nes. 1991. Lactococcin $A$, a new bacteriocin from Lactococcus lactis subsp. cremoris: isolation and characterization of the protein and its gene. Journal of Bacteriology:3879-87.

Hughes, R.J., J.D. Brooker, \& C. Smyl. 2005. Growth rate of broiler chickens given condensed tannins extracted from grape seed. Aust Poult Sci Symp. 17:65-68.

Incharoen, T. 2013. Histological Adaptations Of The Gastrointestinal Tract Of Broilers Fed Diets Containing Insoluble Fiber From Rice Hull Meal. American Journal Of Animal And Veterinary Sciences. Vol 8(2):79-88.

Krisnan, Rantan, \& Ginting. 2009. Penggunaan Solid Ex-Decanter Sebagai Perekat Pembuatan Pakan Komplit Berbentuk Pelet: Evaluasi Fisik Pakan Komplit Berbentuk Pelet. Proseding Seminar Nasional Teknologi Peternakan dan Veteriner. Loka Penelitian Kambing Potong: Sumatera Utara. Hal 480-489

Ly, J. 2016. Effect of fermented tamarind seeds (FTS) supplementation to sows during estrus to lactation period on sow reproduction performances and piglet mortality at weaning. Journal of Agricultural Science and Technology A 7:493-500. http://doi.org/10.17265/ 2161-6256/2017.07.005

McDonald, P., R.A. Edwards \& J.F.D. Greenhalgh. 1994. Animal Nutrition. 4th ed. Longman Scientific and Technical. New York.

Mohamded, Aliyu, \& Mundi. 2013 Effect of bitter kola (Garcinia kola) as a dietary additive on the performance of broiler chicks. Journal of Environment and Ecology 4(2):

Ouyang, K., M. Xu, Y. Jiang, \& W. Wang. 2016. Effects of alfalfa flavonoids on broiler performance, meat quality, and gene expression. J. Anim. Sci. 96:332-341. https://doi.org/10.1139/cjas-2015-0132

Pugalenthi, M., V. Vadivel., P. Gurumoorthi \& K. Janardhanan. 2004. Comparative nutritional evaluation of little known legumes, Tamarindus indica, Erythrina indica and Sesbania bispinosa. Tropical and Subtropical Agroecosystems (4): 107-123.

Ritthiwigrom, Laphookhieo Pyne Sg. 2013. Chemical Constituents And Biological Activities Of Garcinia Cowa Roxb. Maejo Int J Sci Technol. 7:212-231.

Syamsudin, S. Tjokrosonto, S. Wahyuono, \& Mustofa. 2007. Aktivitas antiplasmodium dari dua fraksi ekstrak n-heksana kulit batang asam kandis (Garcinia parvifolia Miq). Majalah Farmasi Indonesia 18(4):210-215.

Tillman, A.D., Hartadi, S. Reksodiprodjo, S. Prwawirokusomo, \& S. Lebdosoekojo. 1989. Ilmu Makanan Ternak Dasar. Gadjah Mada University Press, Yogyakarta

Uji T. 2007. Keanekaragaman, Persebaran, Dan Potensi Jenis-Jenis Garcinia di Indonesia. Berkala Penelitian Hayati 12(129-135).

USDA. 1999. Practical Procedures for Grain Handlers: Inpecting Grain. United States Department of Agriculture-Grain Inspection, Packers And Stockyards Aministration. Washington DC.

Widodo, W. 2014. Ilmu Nutrisi Ternak Unggas. UMM Press. Malang. 